\title{
EFFECT OF GROWING MEDIA AND CHEMICAL FERTILIZATION ON GROWTH AND CHEMICAL COMPOSITION OF Khaya senegalensis (DESR.) AFRICAN MAHOGANY
}

(Received: 3.1. 2011)

\author{
By \\ M.A. Darwesh, O.H. El-Shiaty, E.E. Habba* and R.M.B.El-Assaly* \\ Ornamental Horticulture Department, Faculty of Agriculture, Cairo University, Egypt. \\ *Ornamental Plants and Woody Trees Department, National Research Centre, El-Dokki, Giza, Egypt.
}

\begin{abstract}
This investigation was carried out at the Ornamental Horticulture Department, Faculty of Agriculture, Cairo University, Egypt during two successive seasons; 2007 and 2008, aiming to study the effect of different growing media (clay, sand, and clay + sand 1:1 by volume) and NPK (4:4:1) fertilization at different rates $(0,2,4$ and $6 \mathrm{~g} / \mathrm{pot})$ on the growth and chemical composition of Khaya senegalensis seedlings.

The results showed that growing the plants in clay medium gave the highest values of plant height, stem diameter, number of leaflets/plant, chlorophyll ( $\mathrm{a}$ and $\mathrm{b}$ ) contents and total carbohydrates in the root, in both seasons. Whereas sand medium gave the highest value of carotenoids in the first season, but in the second season clay medium gave the highest value of carotenoids. While the clay + sand medium gave the highest values of total carbohydrates in the leaves and the stems.

NPK at $6 \mathrm{~g} /$ plant increased plant height, stem diameter, number of leaflets/plant and chlorophyll (a and b) contents. Whereas NPK at $4 \mathrm{~g} /$ plant increased total carbohydrates content in the leaves and the application of NPK at $2 \mathrm{~g} /$ plant increased total carbohydrates content in the stems and the roots in both seasons. All NPK fertilization treatments gradually decreased carotenoids content as compared with the control plants in the first season, but all NPK fertilization treatments significantly increased carotenoids contents compared with the control plants in the second season.

Using clay combined with NPK at $6 \mathrm{~g} /$ plant gave the highest values of most characters. The highest value of carotenoids content was obtained from $2 \mathrm{~g} \mathrm{NPK/plant} \mathrm{combined} \mathrm{with} \mathrm{sand} \mathrm{soil} \mathrm{in} \mathrm{the} \mathrm{first}$ season, but in the second season the highest value of carotenoids content. While using clay + sand or clay medium fertilized with NPK at $4 \mathrm{~g} / \mathrm{plant}$ gave the highest values of total carbohydrates in the leaves. Plants grown in clay + sand medium and treated with $2 \mathrm{~g} \mathrm{NPK} /$ plant gave the highest values of total carbohydrates in the stems, in both seasons. Whereas using clay soil treated with NPK at $2 \mathrm{~g} / \mathrm{plant}$ gave the highest values of total carbohydrates in the roots in the first and second seasons.
\end{abstract}

Key words: African mahogany, Khaya senegalensis, meliaceae, NPK fertilization, soil media.

\section{INTRODUCTION}

African mahogany ( Khaya senegalensis Desr.) Fam. Meliaceae is a tree. The natural distribution area of Khaya tree is from Senegal to Sudan and Uganda. Khaya tree can reach $(15 \mathrm{~m}$ to $24 \mathrm{~m})$ in height with a stem diameter of about $(1.0 \mathrm{~m}$.), it is semi-deciduous. Leaves are compound (18-30 $\mathrm{cm}$.) long. Flowers are white, the fruit is capsule with 4 valves. $K$. senegalensis wood used for many purposes, as furniture, cabinet's veneers interiors, turning and interior accent. Khaya is an important timber tree for industry, in addition to its medicinal values, especially the bark, which is used to treat a number of diseases, such as fever, lumbago, cough, rheumatism and stomach ache and also gastiric pains (Kerharo and Bouquet, 1950). The bark is also used in the treatment of worm infestation, ulcer and mucous diarrhea in horses and camels (Dalziel, 1948).

Therefore, growing media is one of the most important factors affecting plant growth and chemical composition. Several investigators revealed that the growing media had a marked effect on vegetative growth and chemical composition; El-Sallami (2003) on Leucaena leucocephala; Kathiravan et al. (2008) on Jatropha curcas; El- Mahrouk et al., (2009) on Cestrum aurantiacum and Azza et al. (2010) on Jatropha curcas L.

Chemical fertilization, especially NPK 
promotes the vegetative growth of tree seedlings. Nitrogen is the most effective element, since it is an essential constituent of proteins, amino acids, alkaloids, some vitamins and co-enzymes. Thus, it plays very important role in metabolism, growth reproduction. Phosphorus is closely concerned with the vital growth processes in plants and as it is present in all cell nuclei as phosphoric acid combined with other constituents to form nucleic acids. It is also of great importance in root growth. Potassium plays an important role in metabolism such as the formation of carbohydrates and proteins, the regulation of water conditions within the plant cell and water loss by transpiration and the photosynthesis process (Jain, 1983).

Also, NPK fertilization affects plant growth and chemical composition; Fan et al. (2000) on Spathiphyllum palls; Jiang et al. (2000) on Phyllostachys iridensce; Kandeel et al. (2002) on Taxodium distichum and El-Mahrouk et al. (2009) on Cestrum aurantiacum;

The aim of this investigation was to find out the best growing media (clay, sand, and mixture of them $1: 1$ by volume) and NPK fertilizer application for the growth and chemical composition of Khaya senegalensis plant.

\section{MATERIALS AND METHODS}

This investigation was carried out at the Ornamental Horticulture Department, Faculty of Agriculture, Cairo University, Egypt during two successive seasons of 2007 and 2008. The aim was to investigate the effect of growing media and NPK (4:4:1) fertilization on the growth and chemical composition of Khaya senegalensis seedlings.

Homogenous seedlings of African mahogany Khaya senegalensis (one-year-old, 20-25 cm height, and 4-6 compound leaf/plant in average) were used as a plant material. The seedlings were introduced from the Forestry Department, Agricultural Research Center, Giza, Egypt.

The seedlings were planted in April $15^{\text {th }} 2007$ and 2008 for the first and second seasons, respectively. They were planted in $30 \mathrm{~cm}$ plastic pots (one seedling/pot) filled with one of the different growing media used, i.e., clay, sand, and the mixture of them $1: 1(\mathrm{~V} / \mathrm{V})$.

The plants received the first application of fertilizer after two months from transplanting .The Khaya senegalensis plants were fertilized with different rates $(0,2,4$ and $6 \mathrm{~g} /$ pot $)$ of a mixture containing (ammonium nitrate $\mathrm{N} \mathrm{33.0 \%} \mathrm{+} \mathrm{calcium}$ superphosphate $\mathrm{P}_{2} \mathrm{O}_{5} 15.5 \%$ + potassium sulphate $\mathrm{K}_{2} \mathrm{O} 48.0 \%$ ) at the ratio of (4: 4: 1). Plants were fertilized 6 times during the growing season starting from June $15^{\text {th }}$ till November $15^{\text {th }}$ at 30 day- intervals. The fertilizers were applied as top dressing to the pots then irrigation water was added.

The layout of the experiment was a completely randomized in factorial design as including 12 treatments with 9 replicates. Growing media represented as main plot, while chemical fertilization treatments represented as sub plot. Each replicate contained one plant.

The following data were recorded at the end of the experiment: plant height $(\mathrm{cm})$, stem diameter $(\mathrm{cm})$, number of leaflets, pigments (chlorophyll a, chlorophyll b and carotenoids) content in the leaves (mg/g F.W.) and total carbohydrates content in the leaves, the stems and the roots (\% D.W.) were determined.

Chlorophyll a, b and total carotenoid contents were determined in leaf samples (mg/gm F.W.) according to Nornai (1982). Total carbohydrates content was determined according to Dubois et al. (1956).

Data recorded on vegetative growth, were statistically analyzed, and separation of means was performed using the Least Significant Difference (L.S.D.) test at the 5\% level, as described by (Snedecor and Cochran, 1980).

\section{RESULTS AND DISCUSSION}

\subsection{Effect of growing media and NPK fertilization on the vegetative growth of Khaya senegalensis}

\subsubsection{Plant height}

The results in Table (1) indicate that using various growing media had significant effect between three growing media on the plant height. Plants grown in clay soil resulted in the best results $(83.46$ and $85.38 \mathrm{~cm})$ in the first and second seasons, respectively as compared with sand soil or clay + sand soil. Similar results were obtained by Darwish (1994) on Casuarina glauca and Populus nigra, Kathiravan et al. (2008) on Jatropha curcas and Azza et al. (2010) on Jatropha curcas L.

High rate of NPK fertilizer (6 g/ plant) stimulated plant height $(71.61$ and $89.06 \mathrm{~cm})$ compared with the control and other treatments of fertilizers ( 2 or $4 \mathrm{~g} / \mathrm{plant}$ ) in the first and second seasons, respectively. These results are in agreement with those obtained by El-Mahrouk et al. (2009) on Cestrum aurantiacum,

Interaction between growing media and chemical fertilization had a significant effect on plant height. Clay soil supplemented with 6 
g/plant of NPK gave the highest increment (94.83 and $99.67 \mathrm{~cm}$ ) in the first and second seasons, respectively. While the untreated plants grown in sandy soil were the shortest as with values (32.17 and $39.33 \mathrm{~cm})$ in the first and second seasons, respectively. The results go in line with those obtained by El-Mahrouk et al. (2009) on Cestrum aurantiacum.

\subsubsection{Stem diameter}

The data in Table (1) pointed out that clay soil as a growing medium gave the best results of stem diameter followed by clay + sand and sand media in the first and second seasons. These results were confirmed with those obtained by Abdullah and Ali (1985) on Pinus brutia, Darwish (1994) on Casuarina glauca and Populus nigra, El-Mahrouk et al. (2009) on Cestrum aurantiacum and Azza et al. (2010) on Jatropha curcas.

Fertilization with NPK at $6 \mathrm{~g} / \mathrm{plant}$ produced the highest values $(1.28$ and $1.48 \mathrm{~cm})$ of stem diameter in both seasons, respectively. While gradual decreasing of NPK fertilization to 4,2 or $0 \mathrm{~g} / \mathrm{plant}$ decreased stem diameter to the lowest values, in the first and second seasons. Similar results were obtained by Kandeel et al. (2002) on Taxodium distichum and El-Mahrouk et al. (2009) on Cestrum aurantiacum.

Interaction between growing media and chemical fertilization had a non significant effect on stem diameter in the first season and a significant effect in the second season. The highest values $(1.42$ and $1.85 \mathrm{~cm})$ were obtained from the plants growing in clay $+6 \mathrm{~g}$ NPK/plant in the first and second seasons, respectively as compared with other treatments whereas the least values were obtained from the plant growing in sand soil without fertilization. The results go in line with those obtained by El-Mahrouk et al. (2009) on Cestrum aurantiacum.

Table (1): Effect of growing media and NPK fertilization on plant height (cm), stem diameter (cm) and number of leaflets of Khaya senegalensis Desr. during the two seasons 2007 and 2008.

\begin{tabular}{|c|c|c|c|c|c|c|c|c|}
\hline \multirow[t]{3}{*}{ Fertilization (B) } & \multicolumn{8}{|c|}{ Soil media (A) } \\
\hline & Sand & Clay & $\begin{array}{c}\text { Sand+ } \\
\text { Clay }\end{array}$ & Mean & Sand & Clay & $\begin{array}{c}\text { Sand+ } \\
\text { Clay }\end{array}$ & Mean \\
\hline & \multicolumn{4}{|c|}{2007} & \multicolumn{4}{|c|}{2008} \\
\hline \multicolumn{9}{|c|}{ Plant height $(\mathbf{c m})$} \\
\hline Control & 32.17 & 73.93 & 53.83 & 53.39 & 39.33 & 67.83 & 61.50 & 56.22 \\
\hline 2gm NPK & 41.33 & 79.83 & 61.17 & 60.78 & 56.83 & 80.17 & 74.83 & 70.61 \\
\hline $4 \mathrm{gm}$ NPK & 45.17 & 85.00 & 60.00 & 63.72 & 62.17 & 93.83 & 85.67 & 80.56 \\
\hline 6gm NPK & 50.17 & 94.83 & 64.17 & 71.61 & 72.50 & 99.67 & 95.00 & 89.06 \\
\hline Mean & 42.71 & 83.46 & 61.83 & & 57.71 & 85.38 & 79.25 & \\
\hline LSD at 0.05 for: & & & & & & & & \\
\hline $\mathbf{A}$ & \multicolumn{4}{|c|}{1.36} & \multicolumn{4}{|c|}{1.04} \\
\hline B & \multirow{2}{*}{\multicolumn{4}{|c|}{$\begin{array}{l}1.57 \\
2.72\end{array}$}} & \multicolumn{4}{|c|}{1.20} \\
\hline $\mathbf{A B}$ & & & & & & & & \\
\hline \multicolumn{9}{|c|}{ Stem dia } \\
\hline Control & 0.73 & 1.15 & 1.05 & 0.98 & 0.76 & 1.10 & 0.94 & 0.93 \\
\hline $2 \mathrm{gm} \mathrm{NPK}$ & 0.88 & 1.25 & 1.13 & 1.09 & 0.85 & 1.26 & 1.22 & 1.11 \\
\hline $4 \mathrm{gm}$ NPK & 1.00 & 1.36 & 1.18 & 1.18 & 0.93 & 1.53 & 1.42 & 1.29 \\
\hline 6gm NPK & 1.10 & 1.42 & 1.27 & 1.28 & 1.01 & 1.85 & 1.57 & 1.48 \\
\hline Mean & 0.93 & 1.31 & 1.16 & & 0.89 & 1.43 & 1.29 & \\
\hline LSD at 0.05 for: & & & & & & & & \\
\hline $\mathbf{A}$ & \multicolumn{4}{|c|}{0.20} & \multicolumn{4}{|c|}{0.29} \\
\hline B & \multirow{2}{*}{\multicolumn{4}{|c|}{0.24}} & \multicolumn{4}{|c|}{0.34} \\
\hline $\mathbf{A B}$ & & & & & & & & \\
\hline \multicolumn{9}{|c|}{ Number of 1} \\
\hline Control & 21.33 & 108.00 & 67.00 & 65.44 & 41.67 & 114.67 & 97.33 & 84.56 \\
\hline $2 \mathrm{gm} \mathrm{NPK}$ & 49.33 & 156.00 & 99.33 & 101.55 & 91.00 & 126.67 & 169.00 & 128.89 \\
\hline $4 \operatorname{lgm}$ NPK & 85.33 & 196.67 & 73.33 & 118.44 & 103.00 & 146.67 & 145.33 & 131.67 \\
\hline 6gm NPK & 71.67 & 246.33 & 72.00 & 130.00 & 73.33 & 179.33 & 144.67 & 132.44 \\
\hline Mean & 56.92 & 176.75 & 77.92 & & 77.25 & 141.84 & 139.08 & \\
\hline LSD at 0.05 for: & & & & & & & & \\
\hline $\mathbf{A}$ & \multicolumn{4}{|c|}{7.11} & \multicolumn{4}{|c|}{6.93} \\
\hline B & \multirow{2}{*}{\multicolumn{4}{|c|}{$\begin{array}{c}8.21 \\
14.23\end{array}$}} & \multicolumn{4}{|c|}{8.01} \\
\hline AB & & & & 14.23 & \multicolumn{4}{|c|}{13.87} \\
\hline
\end{tabular}




\subsubsection{Number of leaflets/plant}

Concerning the effect of different growing media, it is evident from Table (1) that clay soil significantly increased the number of leaflets formed per plant (176.75 and 141.84) in the first and second seasons, respectively compared with sand or clay + sand soil, which gave the lowest values. These results are in agreement with those obtained by Darwish (1994) on Populus nigra, and Kathiravan et al. (2008) on Jatropha curcas.

Fertilization with various rates of NPK had a significant effect on the number of leaflets/plant compared with the control. The highest values (130.00 and 132.44) were obtained when $6 \mathrm{~g}$ NPK/plant was used in the first and second seasons, respectively as compared with the control, which gave the lowest values. These results are in harmony with those obtained by Kandeel et al. (2002) on Taxodium distichum.

Interaction between growing media and chemical fertilization had a significant effect on the number of leaflets/plant in both seasons. The highest values (246.33 and 179.33) were obtained from the plants growing in clay soil supplemented with $6 \mathrm{~g} \mathrm{NPK} /$ plant in the first and second seasons, respectively. Whereas the lowest values were obtained from the plants growing in sandy soil without fertilization. The promoting effect of clay soil on vegetative growth may due to its effect as a result of absorption more $\mathrm{N}, \mathrm{P}$ and $\mathrm{K}$ as well as to enhance the vegetative growth; ElSallami and Makary (2001) on Thuja orientalis.

\subsection{Effect of growing media and NPK fertilization on chemical compositions of Khaya senegalensis}

\subsubsection{Pigments content in the leaves.}

As shown in Table (2) plants grown in clay soil gave the highest chlorophyll a and chlorophyll $b$ contents in the leaves followed by (sand + clay) and sand media in the first and second seasons, respectively. These results are in harmony with those obtained by El-Sallami and Makary (2001) on Thuja orientalis, El-Sallami (2003) on Leucaena leucocephala, El-Mahrouk et al. (2009) on Cestrum aurantiacum and Azza et al. (2010) on Jatropha curcas. On the other hand, plants grown in sandy soil gave the best results of carotenoids content $(0.35)$ compared with (sand + clay) or clay soil in the first season. Whereas in the second season, plants grown in clay soil gave the highest value of carotenoids content (0.43) compared with (sand + clay) or sandy soil. Similar results were obtained by Mohamed (1993) on Adhatoda vasica, Nerium oleander, El-Sallami (2003) on Leucaena leucocephala and Azza et al.
(2010) on Jatropha curcas.

Chemical fertilization treatments significantly increased chlorophyll (a and b) contents compared with the control in the first and second seasons. The best results were obtained from $6 \mathrm{~g}$ NPK/plant in the first and second seasons. These results are in agreement with those obtained by Collared et al. (1977) on Ficus benjamina and ElKhateeb (1983) on Eucalyptus torquata and Eucalyptus angulosa. On the other hand, all NPK fertilization treatments gradually decreased carotenoid contents compared with the control in the first season. While all fertilization treatments significantly increased carotenoids compared with the control in the second season. The best value (0.31) was produced from the control plants and the lowest value $(0.23)$ was obtained from $6 \mathrm{~g}$ NPK/plant in the first season. Similar results were obtained by El-Khateeb (1983) on Eucalyptus torquata and Eucalyptus angulosa,. While in the second season the best value (0.47) was obtained from $6 \mathrm{~g} \mathrm{NPK/plant} \mathrm{and} \mathrm{the} \mathrm{lowest} \mathrm{value} \mathrm{was}$ produced from the control plants. Similar results were obtained by Mansour (1985) on Chamaedorea spp. and Farahat (1986) on Eucalyptus camaldulensis.

Interaction between growing media and chemical fertilization had a significant effect on chlorophyll (a) and carotenoid contents in the first season. While it had no significant effect in the second season on chlorophyll (a , b) and carotenoid content. Plants grown in clay soil and fertilized with $6 \mathrm{~g}$ NPK/plant gave the highest chlorophyll $(\mathrm{a}, \mathrm{b})$ contents in the first and second seasons. The lowest values were obtained from the plants growing in sandy soil and untreated (control) in both seasons. On the other hand, the highest value of carotenoids (0.44) was obtained from $2 \mathrm{~g} \mathrm{NPK} /$ plant combined with sandy soil in the first season. Whereas in the second season, the highest value $(0.52)$ was obtained from plants fertilized by $6 \mathrm{~g}$ NPK/plant combined with clay soil. While, the lowest values ( 0.24 and 0.19$)$ were obtained from plants growing in sandy soil and untreated (control) in the first and second season, respectively.

\subsubsection{Total carbohydrate contents in the leaves}

The results presented in Table (3) showed that using various growing media had significant effect on the total carbohydrates in the leaves. Plants grown in (clay + sand) media gave the highest total carbohydrates in the leaves, when compared with clay and sand media in the first and second seasons. These results are in agreement with those obtained by El-Sallami (1996) on Ficus benjamina 
and El-Mahrouk et al. (2009) on Cestrum aurantiacum.

All chemical fertilization treatments increased total carbohydrates in the leaves as compared with the control plants except NPK at $6 \mathrm{~g} / \mathrm{plant}$, which decreased it, in the first season. Whereas in the second season, all the treatments increased the total carbohydrates in the leaves compared with the control plants. The best results (30.78 and $22.00 \%)$ in the first and second seasons, respectively were obtained from plants treated with NPK at $4 \mathrm{~g} / \mathrm{plant}$. Similar results were obtained by El-Khateeb (1983) on Eucalyptus torquata and E. angulosa, Mansour (1985) on Chamadorea elegans, and El-Khateeb and Salem
(1988) on Thuja oriantalis.

The interaction between soil media and chemical fertilization had a non significant effect on total carbohydrates in the leaves, in the first season and it had a significant effect in the second season. Plants grown in clay and sand media and treated with NPK $4 \mathrm{~g} /$ plant gave the highest total carbohydrates in the leaves $(35.65 \%)$, in the first season. While in the second season, the plants grown in clay soil and treated with NPK at $4 \mathrm{~g} /$ plant gave the highest total carbohydrate content in the leaves (25.53\%) followed by plants grown in clay and sand soil and treated with NPK at $4 \mathrm{~g} /$ plant $(25.45 \%)$.Whereas the lowest result was

Table (2): Effect of growing media and NPK fertilization on chlorophyll a (mg/g. F.W.) and chlorophyll b (mg/g. F.W.) and carotenoids (mg/g. F.W.)of Khaya senegalensis Desr. during the two seasons 2007 and 2008.

\begin{tabular}{|c|c|c|c|c|c|c|c|c|}
\hline \multirow[t]{3}{*}{ Fertilization (B) } & \multicolumn{8}{|c|}{ Soil media (A) } \\
\hline & Sand & Clay & $\begin{array}{c}\text { Sand+ } \\
\text { Clay }\end{array}$ & Mean & Sand & Clay & $\begin{array}{l}\text { Sand } \\
+ \text { Clay }\end{array}$ & Mean \\
\hline & \multicolumn{4}{|c|}{2007} & \multicolumn{4}{|c|}{2008} \\
\hline \multicolumn{9}{|c|}{ Chlorophyll a (mg/g. F.W.) } \\
\hline $\begin{array}{l}\text { Control } \\
\text { 2gm NPK } \\
\text { 4gm NPK } \\
\text { 6gm NPK } \\
\text { Mean } \\
\text { LSD at } 0.05 \text { for: } \\
\text { A } \\
\text { B } \\
\text { AB }\end{array}$ & $\begin{array}{l}0.33 \\
0.64 \\
0.87 \\
0.98 \\
0.71\end{array}$ & $\begin{array}{l}0.75 \\
0.86 \\
0.90 \\
1.03 \\
0.89\end{array}$ & $\begin{array}{l}0.69 \\
0.72 \\
0.79 \\
0.84 \\
0.76\end{array}$ & $\begin{array}{l}0.59 \\
0.74 \\
0.85 \\
0.95\end{array}$ & $\begin{array}{l}0.30 \\
0.79 \\
0.94 \\
0.97 \\
0.75\end{array}$ & $\begin{array}{l}0.85 \\
1.04 \\
1.17 \\
1.35 \\
1.10\end{array}$ & $\begin{array}{l}0.69 \\
0.88 \\
1.05 \\
1.13 \\
0.94\end{array}$ & $\begin{array}{l}0.61 \\
0.90 \\
1.05 \\
1.15\end{array}$ \\
\hline \multicolumn{9}{|c|}{ Chlorophyll b (mg/g. F.W.) } \\
\hline $\begin{array}{l}\text { Control } \\
\text { 2gm NPK } \\
\text { 4gm NPK } \\
\text { 6gm NPK } \\
\text { Mean } \\
\text { LSD at } 0.05 \text { for: } \\
\text { A } \\
\text { B } \\
\text { AB } \\
\end{array}$ & $\begin{array}{l}0.12 \\
0.29 \\
0.32 \\
0.38 \\
0.28\end{array}$ & $\begin{array}{l}0.28 \\
0.48 \\
0.49 \\
0.54 \\
0.45\end{array}$ & $\begin{array}{l}0.23 \\
0.45 \\
0.48 \\
0.53 \\
0.42\end{array}$ & $\begin{array}{l}0.21 \\
0.41 \\
0.43 \\
0.48\end{array}$ & $\begin{array}{l}0.23 \\
0.38 \\
0.53 \\
0.60 \\
0.44\end{array}$ & $\begin{array}{l}0.49 \\
0.61 \\
0.67 \\
0.82 \\
0.65\end{array}$ & $\begin{array}{l}0.40 \\
0.47 \\
0.55 \\
0.72 \\
0.54 \\
5 \\
9 \\
5 . \\
\end{array}$ & $\begin{array}{l}0.37 \\
0.49 \\
0.58 \\
0.71\end{array}$ \\
\hline \multicolumn{9}{|c|}{ Carotenoids (mg/g. F.W.) } \\
\hline $\begin{array}{l}\text { Control } \\
\text { 2gm NPK } \\
\text { 4gm NPK } \\
\text { 6gm NPK } \\
\text { Mean } \\
\text { LSD at } 0.05 \text { for: } \\
\text { A } \\
\text { B } \\
\text { AB }\end{array}$ & $\begin{array}{l}0.24 \\
0.44 \\
0.38 \\
0.33 \\
0.35\end{array}$ & $\begin{array}{l}0.33 \\
0.25 \\
0.25 \\
0.19 \\
0.26\end{array}$ & $\begin{array}{l}0.36 \\
0.20 \\
0.19 \\
0.17 \\
0.23\end{array}$ & $\begin{array}{l}0.31 \\
0.30 \\
0.27 \\
0.23\end{array}$ & $\begin{array}{l}0.19 \\
0.40 \\
0.41 \\
0.42 \\
0.36\end{array}$ & $\begin{array}{l}0.34 \\
0.41 \\
0.45 \\
0.52 \\
0.43\end{array}$ & $\begin{array}{l}0.27 \\
0.31 \\
0.37 \\
0.47 \\
0.36\end{array}$ & $\begin{array}{l}0.27 \\
0.37 \\
0.41 \\
0.47\end{array}$ \\
\hline
\end{tabular}


obtained from plants growing in sand soil and fertilized with NPK at $6 \mathrm{~g} / \mathrm{plant}(15.91 \%)$ in the first. While the lowest result in the second season was obtained from the plants grown in sand soil and unfertilized (the control) which gave $(17.76 \%)$.

\subsubsection{Total carbohydrates content in the stems}

As shown in Table (3) plants grown in clay + sandy soil gave the highest total carbohydrate content in the stems as compared with the plants grown in clay or sandy soil in both seasons. These results are in harmony with those obtained by Farahat (1986) on Eucalyptus camaldulensis, ElSallami (1996) on Ficus benjamina and ElMahrouk et al. (2009) on Cestrum aurantiacum.

All chemical fertilizations increased the total carbohydrate content in the stems compared with the control plants in the first and the second seasons. The best results were obtained from plants treated with NPK at $2 \mathrm{~g} / \mathrm{plant}$ followed by 4 $\mathrm{g}$ NPK /plant and $6 \mathrm{~g}$ NPK /plant in the first and second seasons. These results are in agreement with those obtained by Mansour (1985) on Chamadorea elegans and El-Khateeb and Salem (1988) on Thuja oriantalis.

The interaction between growing media and chemical fertilization had a significant effect on the total carbohydrates content in the stems in the first and second seasons. The best results were obtained from plants grown in clay + sand soil and treated with NPK at $2 \mathrm{~g} / \mathrm{plant}$, in both seasons. Whereas the lowest values were obtained from plants growing in sand soil and untreated with fertilizer (control) followed by plants grown in sand soil and treated with NPK at $6 \mathrm{~g} /$ plant, in the first season. In the second season; plants grown in

Table (3): Effect of growing media and NPK fertilization on total carbohydrates content in the leaves, the stems and the roots (\%)of Khaya senegalensis Desr. during the two seasons 2007 and 2008.

\begin{tabular}{|c|c|c|c|c|c|c|c|c|}
\hline \multirow[t]{3}{*}{ Fertilization (B) } & \multicolumn{8}{|c|}{ Soil media (A) } \\
\hline & Sand & Clay & $\begin{array}{c}\text { Sand+ } \\
\text { Clay }\end{array}$ & Mean & Sand & Clay & $\begin{array}{l}\text { Sand } \\
+ \text { Clay }\end{array}$ & Mean \\
\hline & \multicolumn{4}{|c|}{2007} & \multicolumn{4}{|c|}{2008} \\
\hline \multicolumn{9}{|c|}{ Total carbohydrates content in the leaves (\%) } \\
\hline Control & 19.90 & 26.77 & 29.39 & 25.35 & 17.76 & 18.86 & 19.22 & 18.61 \\
\hline 2gm NPK & 22.76 & 27.83 & 30.11 & 26.90 & 18.34 & 19.52 & 21.32 & 19.73 \\
\hline $4 g m$ NPK & 25.41 & 31.29 & 35.65 & 30.78 & 20.03 & 25.53 & 25.45 & 22.00 \\
\hline 6gm NPK & 15.91 & 20.31 & 25.48 & 20.57 & 19.70 & 17.79 & 20.86 & 19.45 \\
\hline Mean & 21.00 & 26.55 & 30.16 & & 18.96 & 19.17 & 21.71 & \\
\hline LSD at 0.05 for: & \multirow{2}{*}{\multicolumn{4}{|c|}{1.58}} & & & & \\
\hline A & & & & & \multicolumn{4}{|c|}{1.02} \\
\hline B & \multicolumn{4}{|c|}{1.82} & \multicolumn{4}{|c|}{1.18} \\
\hline $\mathbf{A B}$ & \multicolumn{4}{|c|}{ N.S. } & \multicolumn{4}{|c|}{2.05} \\
\hline \multicolumn{9}{|c|}{ Total carbohydrates content in the stems $(\%)$} \\
\hline Control & 51.03 & 52.25 & 54.25 & 52.51 & 15.60 & 17.13 & 17.68 & 16.80 \\
\hline $2 \mathrm{gm}$ NPK & 54.01 & 63.06 & 63.36 & 60.14 & 23.82 & 29.74 & 30.31 & 27.96 \\
\hline 4gm NPK & 52.92 & 55.82 & 55.18 & 54.64 & 19.05 & 25.14 & 27.80 & 24.00 \\
\hline 6gm NPK & 52.21 & 52.82 & 53.25 & 52.76 & 14.19 & 21.81 & 24.26 & 20.09 \\
\hline Mean & 52.54 & 55.99 & 56.51 & & 18.17 & 23.46 & 25.01 & \\
\hline LSD at & & & & & & & & \\
\hline $\mathbf{A}$ & \multicolumn{4}{|c|}{2.07} & \multicolumn{4}{|c|}{1.40} \\
\hline B & \multicolumn{4}{|c|}{2.38} & \multicolumn{4}{|c|}{1.62} \\
\hline $\mathbf{A B}$ & \multicolumn{4}{|c|}{4.13} & \multicolumn{4}{|c|}{2.80} \\
\hline \multicolumn{9}{|c|}{ Total carbohydrates content in the roots (\%) } \\
\hline Control & 39.66 & 37.24 & 32.07 & 36.32 & 27.46 & 18.39 & 16.68 & 20.84 \\
\hline $2 \mathrm{gm}$ NPK & 53.34 & 64.16 & 45.91 & 54.47 & 32.45 & 35.98 & 35.60 & 34.68 \\
\hline $4 \mathrm{gm}$ NPK & 41.81 & 51.47 & 39.33 & 44.20 & 22.38 & 25.27 & 23.17 & 23.61 \\
\hline 6gm NPK & 32.99 & 41.33 & 31.16 & 35.16 & 19.22 & 23.47 & 19.83 & 20.84 \\
\hline Mean & 41.95 & 48.55 & 37.12 & & 25.38 & 25.78 & 19.83 & \\
\hline LSD at 0 & & & & & & & & \\
\hline $\mathbf{A}$ & \multicolumn{4}{|c|}{1.25} & \multicolumn{4}{|c|}{ N.S. } \\
\hline B & \multirow{2}{*}{\multicolumn{4}{|c|}{$\begin{array}{l}1.44 \\
2.50\end{array}$}} & \multirow{2}{*}{\multicolumn{4}{|c|}{$\begin{array}{l}3.14 \\
5.45\end{array}$}} \\
\hline $\mathbf{A B}$ & & & & & & & & \\
\hline
\end{tabular}


sand soil combined with NPK at $6 \mathrm{~g} / \mathrm{plant}$ followed by plants growing in sand soil and untreated with fertilizer (control) gave the lowest value.

\subsubsection{Total carbohydrates contents in the roots}

The data in Table (3) showed that clay media gave the highest total carbohydrates content in the roots as compared with sand soil and clay + sand medium, in the first seasons. Whereas in the second season, growing media had no significant effect on total carbohydrates content in the roots. These results are in agreement with those obtained by El-Sallami (1996) on Ficus benjamina and ElMahrouk et al. (2009) on Cestrum aurantiacum.

Chemical fertilization treatments significantly increased total carbohydrate contents in the roots compared with the control plants except NPK at 6 $\mathrm{g} / \mathrm{plant}$, in the first and second seasons. The best results were obtained from plants fertilized by $2 \mathrm{~g}$ $\mathrm{NPK} /$ plant in the first and second seasons. While the lowest value was obtained from plants fertilized with $6 \mathrm{~g} \mathrm{NPK} /$ plant and the control in the first and second seasons. These results are in harmony with those obtained by Mansour (1985) on Chamadorea elegance; 1-Khateeb and Salem (1988) on Thuja oriantalis and Jiang et al. (2000) on Phyllostachys iridenscens.

The interaction between growing media and chemical fertilization had a significant effect on total carbohydrate contents in the roots. The highest values were obtained from the plants growing in clay soil and treated with NPK (2 g/plant) in both seasons. Whereas the lowest values were obtained from plants growing in clay + sandy soil and treated with $6 \mathrm{~g} \mathrm{NPK/plant}$ followed by plants growing in clay + sandy soil and untreated (control), in the first season, while in the second season, plants growing in clay + sandy soil and untreated with fertilizer (control) followed by plants growing in sand soil and treated with NPK at $6 \mathrm{~g} /$ plant. These results are in harmony with those obtained by El- Tantawy (1981) on Casuarina equisetifolia.

The results of this experiment can be discussed as follows:

Clay medium improved the vegetative growth of Khaya senegalensis seedlings, compared with the mixture of clay and sand (1:1) or sand soil. These results may be due to the physical and chemical characteristics of the growing media used in this experiment, clay contained higher $\mathrm{NPK}$, it has a higher field capacity $(\mathrm{EC}=40 \%)$, and its electric conductivity (EC) did not exceed $0.71 \mathrm{mmhos} / \mathrm{cm}$. The morphological results were confirmed by the parameters of chemical compositions, since clay medium increased chlorophyll (a and b ) in the branchlets; also this growing medium decreased carotenoids content, whereas sugars content may be affected by moisture content of the plant tissue more than by the growing medium itself.

Khaya senegalensis responded to NPK fertilization at the ratio of $(4: 4: 1)$, the vegetative growth was correlated with raising NPK rates from $2 \mathrm{~g} /$ plant to $4 \mathrm{~g} / \mathrm{plant}$, and the most vigorous growth was obtained with $6 \mathrm{~g} /$ plant. This ratio of (4:4:1) with the optimum rate $6 \mathrm{~g} / \mathrm{plant}$ might render the balance between $\mathrm{N}, \mathrm{P}$ and $\mathrm{K}$ that enhanced growth (Devlin, 1975), as under this balance the availability of minerals (NPK) might be higher to be absorbed by roots of the plants.

These results can be interpreted according to the role of individual element $\mathrm{N}, \mathrm{P}$ and $\mathrm{K}$. Nitrogen is the most effective element, since it is an essential constituent of proteins, nucleic acids, prophyrins, alkaloids, some vitamins and coenzymes. Thus, it plays a very important role in metabolism, growth, reproduction and heredity. Phosphorus promotes root growth, and Potassium plays an important role in metabolism such as photosynthesis and chlorophyll synthesis (Jain, 1983)

In conclusion , clay soil significantly gave the highest values of the most vegetative characters and chemical constituents of Khaya senegalensis seedlings, compared with the mixture of clay and sand $(1: 1)$ or sand soil in both seasons.

Fertilization with NPK at $6 \mathrm{~g} /$ plant produced the highest values of plant height, stem diameter, number of leaflets/plant and chlorophyll ( $a$ and $b$ ).

Using clay soil treated with NPK at $6 \mathrm{~g} / \mathrm{plant}$ gave the best results of most characters.

\section{REFERENCES}

Abdullah Y. S. and Ali H. Y. (1985). The effect of some soil media and levels of nitrogen fertilization on growth of Pinus brutia Ten. transplants in Ninevah nursery. Journal of Agricultural-Sciences, 'ZANCO'. 1985, 3(1): 85-98.

Azza A. M. M., Nahed G. A. and El-Habba E.A.(2010). Impact of different soil media on growth and chemical constituents of Jatropha curca L. grown under water regime. Journal of American Science 6(8): 549-556.

Collard R. C., Joiner J. N., Conover C. A. and Mc Connell D. R. (1977). Influence of shade and fertilizer on light compensation. Point 
of Ficus benjamina. J. Amer. Soc. Hort. Sci. 104(4): 447-449.

Dalziel J. M. (1948). The useful plants of West Tropical Africa. Crown Agents for the Colonies. London. p. 612.

Darwish M. A. (1994). Effect of growing media, chemical fertilization and salinity on growth and chemical composition of Casuarina glauca and Populus nigra. Ph.D. Thesis, Fac. Agric., Cairo Univ., Egypt.

Devlin R. M. (1975). Plant physiology. $3^{\text {rd }}$ : Affiliated East - West Press, New Delhi. Chap., 10,11:159-205.

Dubois M., Smith F., Gilles K. A., Hammilton J. K. and Robers P. A. (1956). Colorimetric methods to determination of sugars and related substances. Anal. Chem., 28(3): 350-356.

El-Khateeb M. A. (1983). Effect of salinity irrigation, chemical fertilization and soil media on growth, flowering, chemical composition and essential oil of Eucalyptus torquata and E. angulosa. Ph.D. Thesis, Fac. Agric., Cairo Univ., Egypt.

El-Khateeb M. A. and Salem M. A. (1988). Effect of chemical fertilization on growth and chemical composition of Thuja oreiantalis L. seedlings J. Agric. Res. Tanta Univ., 14 (2) (11): 925-935.

El-Mahrouk E. M., Kandeel Y.M., Hegazi M. A., Mary N. Nasr and Amani I. Adam (2009). Effect of soil type and fertilization treatments on growth and chemical composition of some ornamental shrubs Cestrum aurantiacum (Lindley). Alex. Journal of Agriculture Research. 54(1): 111-121.

El-Sallami I. H. (1996). Response of Ficus benjamina $\mathrm{L}$. to different potting media and doses of nutrient solution. Assiut Journal of Agriculture Science, 27(3): 61-76.

El-Sallami I. H. (2003). Growth response of Leucaena leucocephala Lam. seedlings to soil type, organic manure and yeast. Assiut Journal of Agriculture Science, 34(1): 6798.

El-Sallami I.H. and Makary B. Sh. (2001). Growth and chemical composition of Thuja orientalis L. seedlings as affected by saline irrigation water, soil moisture content and soil type. Assiut Journal of Agriculture Science, 32 (3):61-86.
El-Tantawy A. (1981). Effect of chemical fertilization, soil media and gibberellic acid on growth of some tree seedlings. M.Sc. Thesis, Fac. Agric., Cairo Univ., Egypt.

Fan Y. P., Yu R. C., Chen J. X. and Yang R. T. (2000). Effects of nitrogen nutrition stress on the growth and photosynthetic characteristics of Spathiphyllum palls. Acta Hort., 27(4):297-299.

Farahat M.M. (1986). Some studies on Eucalyptus camaldulensis Dehn. M.Sc. Thesis, Fac. Agric., Cairo Univ., Egypt.

Jain V. K. (1983). Fundamentals of plant physiology. $3^{\text {rd }} \mathrm{Ed}$. S. Chand and Company Ltd. Ram Nagar, New Delhi, 308-310.

Jiang S. H., Zhong C. S. and Zhang G. Z. (2000). Study on the effects of phosphorus, potassium and boron fertilizers on shoot qualities of Phyllostachys iridenscens. Journal of Bamboo Research. 19(1): 48-51.

Kandeel Y. M., El-Tarawy M. A., El-Mahrouk M. M. and Khamis M. H. (2002). Effect of fertilization and irrigation on growth, chemical composition and wood physical properties of Taxodium distichum rich. Transplants. $2^{\text {nd }}$ Conference Horticulture Science, 10-12 Sept. Kafr El-Sheikh, Tanta Univ., 940-955 p.

Kathiravan M., Ponnuswamy A. S. and Vanitha C. (2008). Influence of soil types on elite seedling production in Jatropha (Jatropha curcas) L. Plant Archives, 8(1): 111-113.

Kerharo J. and Bouquet A. (1950). Plantes médicinales de la côte d'Ivoire et Haute Voita, Vigot, Paris, 297p.

Mansour H. A. (1985). Effect of some cultural practices on the production of Aspidistra lurida and two Chamoedorea species. M.Sc. Thesis, Fac. of Agric., Cairo Univ., Egypt.

Mohamed M. F. (1993). Effect of salinity on growth and chemical composition of some ornamental shrubs. M. Sc. Thesis, Fac. Agric., Cairo Univ., Egypt.

Nornai R. (1982). Formula for determination of chlorophyllus pigments extracted with N,Ndimethyl formamide. Plant Physiol., 69:1376-1381.

Snedecor G. W. and Cochran W. G. (1980). Oneway Classification Analysis of Variance. In: Statistical Methods (8 edition). Iowa State University Press, Ames, Iowa, U.S.A., Chapter 12, 217-236. 
تأثير أوساط الزراعة والتسميد الكيماوي على النمو والتركيب الكيماوي

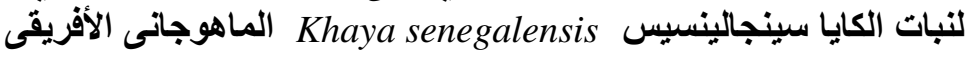

منى أحمد درويش- ألفت حامد الثيتى- إبراهيم الأباصيري حبه*- ريهام تحمد بهجت العليث*

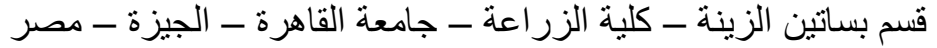

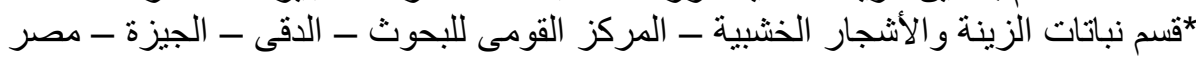

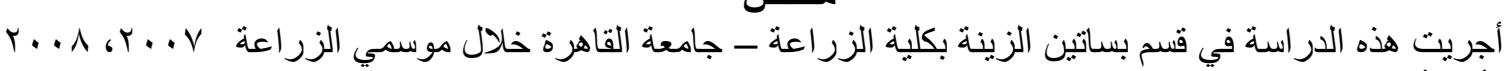

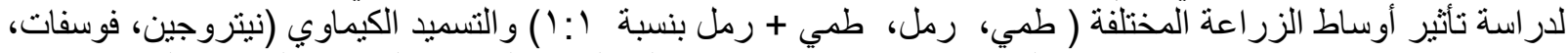

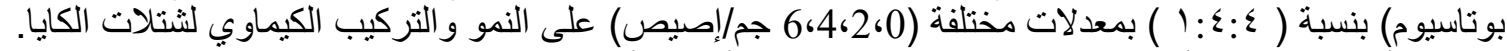

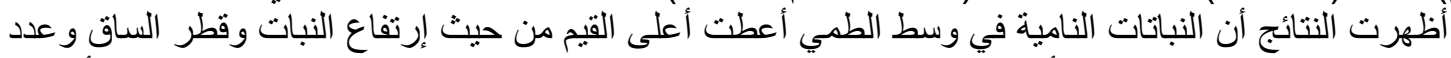

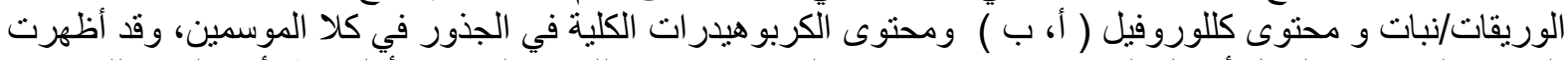

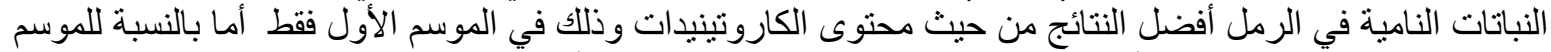

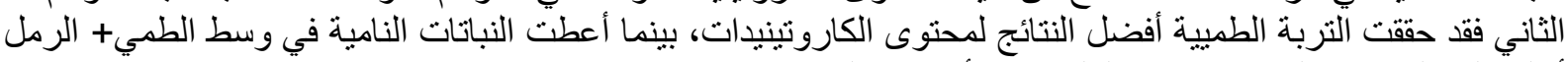

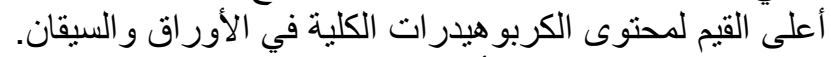

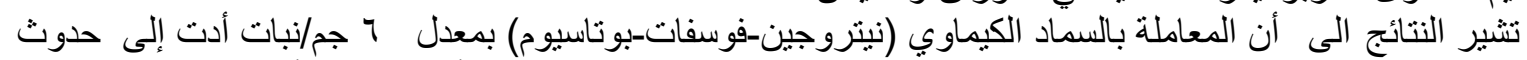

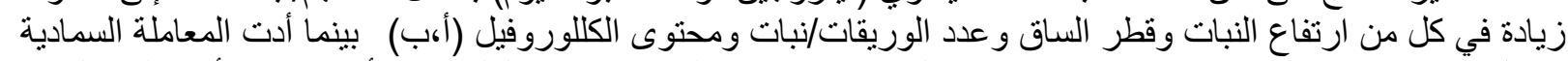

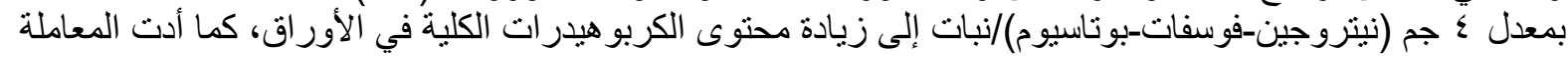

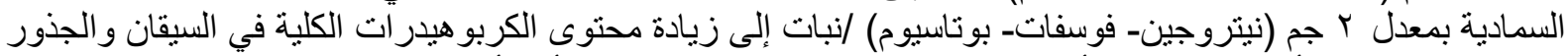

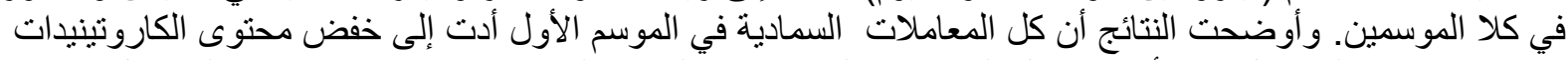

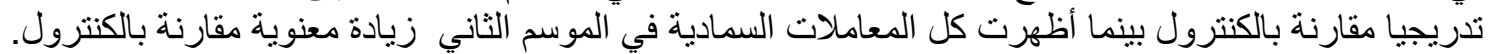

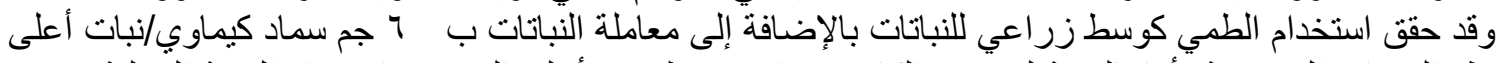

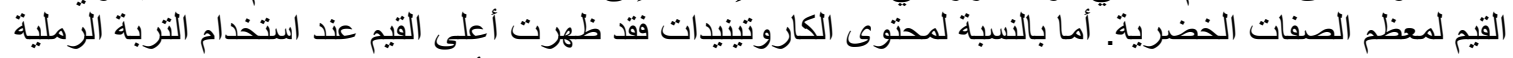

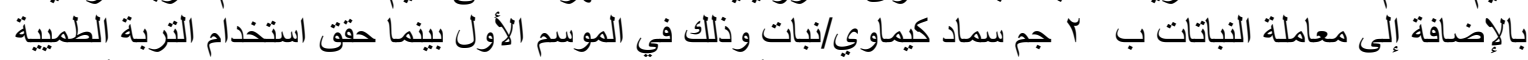

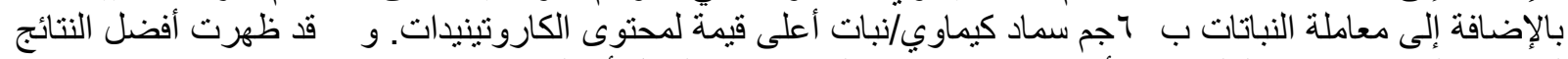

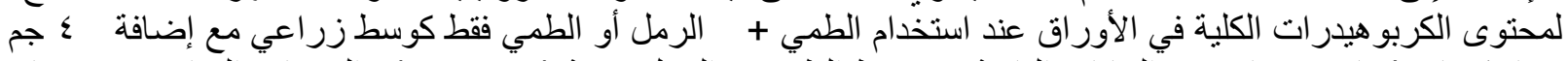

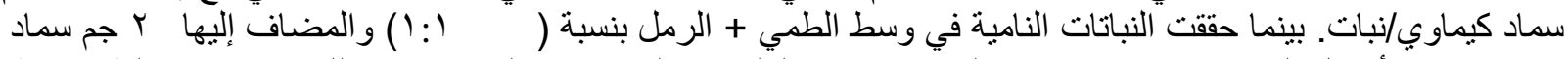

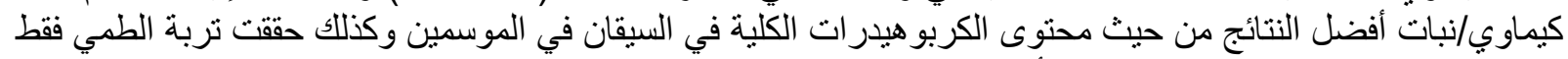

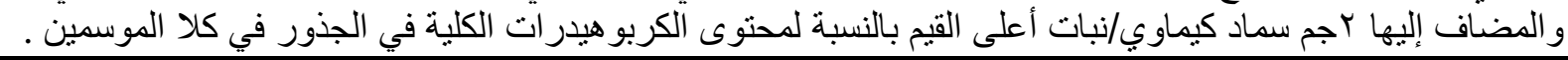

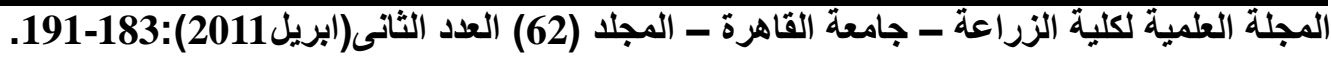

